\title{
Hak untuk Perbicaraan yang Disegerakan dari Perspektif Undang-undang Sivil dan Syariah
}

\section{(The Right to Speedy Trials from the Perspectives of Civil and Syariah Law)}

\author{
FATIMAH HAJI AHMAD \\ ZULAZHAR TAHIR \\ MD KHALIL RUSLAN
}

\begin{abstract}
ABSTRAK
Dalam memperkatakan mengenai perbicaraan jenayah, keutamaan diberikan kepada hak tertuduh mendapat perbicaraan yang adil. Salah satu cabang dari hak tersebut ialah hak perbicaraan segera di mana tertuduh berhak mendapatkan penyelesaian akan tuduhan yang dikenakan ke atasnya dalam jangka waktu yang munasabah. Namun demikian, kelewatan dalam prosiding jenayah adalah isu yang sering berlaku dan kelewatan ini dilihat sebagai sesuatu yang boleh memprejudiskan seseorang tertuduh. Justeru, kajian ini akan mengfokuskan kepada isu kelewatan yang berlaku di dalam perbicaraan-perbicaraan jenayah, dan setakat mana mahkamah dibenarkan oleh undang-undang untuk campur tangan dalam usaha menyelesaikan permasalahan ini. Metodologi kajian perpustakaan diguna pakai yang mana metodologi-metodologi analisis kandungan dan analisis kritis dilaksanakan ke atas statut, artikel serta laporan kes yang berkaitan. Hasil kajian mendapati kuasa campur tangan mahkamah adalah terhad disebabkan kuasa prerogatif yang diberikan kepada pihak pendakwa menurut undang-undang. Kajian ini turut mendapati keperluan keseimbangan di antara hak tertuduh dengan hak kerajaan dan hak masyarakat. Berdasarkan kepada kedua-dua dapatan tersebut, kajian ini mencadangkan supaya semua agensi yang terlibat memainkan peranan masing-masing dengan sebaiknya bagi memastikan kelancaran perbicaraan jenayah demi kepentingan semua pihak iaitu tertuduh, kerajaan dan masyarakat awam.
\end{abstract}

Kata kunci: Hak perbicaraan segera; kelambatan prosiding; kuasa mahkamah; kuasa pendakwa; tatacara jenayah

\section{ABSTRACT}

In discussing criminal proceedings, priority is given towards the accused's right to get a fair trial. One right connected to the right to fair trial is the right to speedy trial in which the accused deserves to an expeditious disposal of the charge against him within a reasonable time. Nevertheless, delays in criminal proceedings is an issue that has been too often reported in case law. Therefore, this research focuses on issues of delays occurring in criminal proceedings, and the limitations within which the courts are allowed by law to interfere in the effort to solve the problem. Library-based research is adopted with the utilisation of content analysis and critical analysis methodologies on relevant statutes, journal articles and reported cases. The research reveals that the courts have limited powers to interfere in consideration of the prerogative powers awarded by law to the prosecution. This research also finds the need to balance between the rights of the accused and the rights of the State and the public. Based on these findings, this research recommends that all involved agencies play their roles in the best way possible in order to ensure smooth running of criminal proceedings for the benefit of all; the accused, the State, and the general public.

Key words: Right to speedy trial; delay in proceedings; power of court; power of prosecutor; criminal procedure

\section{PENGENALAN}

Secara umumnya, tatacara jenayah mempunyai prinsip tersendiri mengenai jangka waktu sesuatu kes itu sepatutnya dikendalikan. Perbicaraan jenayah yang dijalankan dalam tempoh munasabah adalah penting untuk mengelakkan seorang yang dituduh dari berada terlalu lama dalam ketidakpastian tentang nasib yang akan menimpanya. ${ }^{1}$ Dalam masa yang sama, masyarakat juga menginginkan penyelesaian segera terhadap kejadian jenayah yang telah berlaku di kalangan 
mereka, dan mangsa serta saksi juga tidak perlu berada dalam perasaan tidak menentu kerana memikirkan kes yang belum ada penyelesaiannya. ${ }^{2}$ Kesegeraan juga akan memastikan penjenayah dihukum ketika kejadian jenayah berkenaan masih segar dalam ingatan saksi-saksi dan mangsa, sekaligus menghilangkan perbalahan dan rasa tidak senang di kalangan mereka yang terkesan dari jenayah tersebut. ${ }^{3}$

Disebabkan faktor inilah wujudnya pelbagai perkembangan berlaku di dalam pentadbiran keadilan jenayah khususnya bagi memastikan keadilan dicapai bagi pihak-pihak yang terlibat. Prinsip tempoh had masa (limitation period) bagi sesetengah jenayah memberi maksud bahawa kesalahan tersebut perlu diselesaikan dalam tempoh yang ditetapkan. Pelbagai instrumen telah diperkenalkan dalam usaha untuk mempercepatkan perbicaraan seperti mewujudkan peruntukan plea bargaining ${ }^{4}$ yang membolehkan kes diselesaikan tanpa memerlukan masa yang panjang dan kos yang tinggi. ${ }^{5}$ Penggunaan pelbagai anggapan di dalam undang-undang keterangan juga memainkan peranan dalam mempercepatkan perbicaraan keskes jenayah. $^{6}$

Dalam hal ini, perundangan Islam juga turut memberikan penekanan terhadap kesegeraan kes. Pada dasarnya, perbicaraan janganlah dipanjangpanjangkan tanpa keperluan kerana ia boleh menjejaskan keadilan dan mendatangkan kebosanan. ${ }^{7}$ Oleh itu, sebaik sahaja bukti ditegakkan, keraguan dinafikan, dan semua syarat-syarat dipenuhi, maka hakim perlu segera memutuskan kes tersebut. ${ }^{8}$ Ini kerana di dalam sesebuah perbicaraan jenayah, akan adanya keadaan yang mana satu pihak berada dalam kedudukan menzalimi dan satu pihak yang lain dizalimi. Oleh yang demikian, untuk memastikan keadilan dicapai serta kezaliman dapat dihapuskan maka sesuatu perbicaraan itu perlu dilaksanakan dengan seberapa segera yang boleh. $^{9}$ Malahan, ada ulama yang berpendapat apabila hakim berpuas hati dengan sesuatu perbicaraan, wajib baginya menjatuhkan hukuman dengan segera tanpa bertangguh dan kegagalannya berbuat demikian boleh mendatangkan dosa. ${ }^{10}$

Kesegeraan inilah sebab yang mendorong Nabi Muhammad s.a.w. melantik para sahabat menjadi hakimhakim ketika wilayah Islam telah berkembang luas. Ini kerana, adalah sukar bagi baginda menyelesaikan semua kes atau pertikaian yang berlaku di dalam wilayah jajahan Islam, terutama sekali jika keputusan segera diperlukan. Tindakan baginda ini boleh memberi makna bahawa setiap kes perlu diselesaikan dengan baik tanpa penggantungan yang tidak munasabah sehingga boleh mendatangkan kezaliman kepada pihak-pihak yang terlibat. $^{11}$

Dalam erti kata lain, perundangan Islam melihat tindakan melambatkan kes sebagai suatu kezaliman. Atas dasar itu, antara tanggungjawab pemerintah di dalam Islam adalah menyelaraskan urusan manusia berdasarkan perkara yang baik dengan cara mewartakan undang-undang dan peraturan-peraturan bagi mencapai kebaikan dan menghilangkan kezaliman di kalangan rakyatnya. ${ }^{12}$ Akan tetapi, tanggungjawab itu tidak akan terlaksana sepenuhnya sekiranya undang-undang dan peraturan-peraturan tersebut tidak ditadbir dengan baik sehingga akhirnya boleh mendatangkan kezaliman terhadap pihakpihak yang terlibat, termasuk orang yang dituduh melakukan kesalahan jenayah.

Dalam proses untuk berlaku adil, perundangan jenayah Islam menetapkan agar sebarang pertelingkahan dapat diselesaikan dengan segera tanpa birokrasi yang terlalu teknikal. ${ }^{13}$ Walau bagaimanapun, adalah penting bagi seseorang hakim untuk memeriksa kes tersebut dengan teliti agar tidak menjejaskan kekuatan keputusan yang dicapai. ${ }^{14}$ Kepentingan untuk menyegerakan perbicaraan kes di dalam 
perundangan Islam telah dihuraikan secara ringkas tetapi padat oleh Dr. Abdul Karim Zaidan, di mana beliau ada menyebut bahawa:

Dan selagi boleh sesuatu perkara itu dipercepatkan atau dilaksanakan dalam waktu yang singkat, maka itu adalah lebih baik kerana empunya hak tidak lambat dalam mencapai haknya, dan tidak dipanjangkan penantiannya. Akan tetapi, kesegeraan dalam mengeluarkan keputusan tidak bermakna terburu-buru dalam mendengar hujah-hujah dan keterangan-keterangan sehingga hakim gagal mendapat atau memahaminya, atau sehingga menghalangnya dari meneliti dakwaan. ... Apa yang dimaksudkan sebenarnya ialah mengelakkan perkara yang boleh menyebabkan kelambatan, seperti lambat menyediakan alasan penghakiman, menangguhkan kes tanpa sebab, lambat atau enggan mendengar hujah dan keterangan pihak-pihak, atau lambat memberi keputusan apabila pihak-pihak telah memohon supaya kes disegerakan. ${ }^{15}$

Dalam institusi kehakiman syariah semasa, kepentingan untuk menyegerakan kes tetap dititik beratkan. Di dalam suatu perutusan yang telah dibuat oleh Ketua Hakim Syarie Negeri Perlis, beliau telah menyarankan agar semua Hakim Syar'ie mengenal pasti baki kes yang masih belum dapat diselesaikan pada tahun sebelumnya di samping mengenal pasti punca penangguhan, dan sekiranya punca tertangguhnya kes-kes tersebut adalah disebabkan faktor kelemahan mahkamah, maka ia perlulah diperbaiki dan ditangani segera. ${ }^{16}$ Ini dapat menunjukkan kepentingan untuk menyegerakan kes-kes yang dibicarakan di mahkamah untuk tujuan keadilan kepada pihak-pihak yang terlibat.

Begitu juga menurut undang-undang, penyelesaian yang baik memerlukan gabungan pengendalian kes yang adil, penyelesaian yang segera, dan keputusan beralasan kukuh dalam memastikan keadilan dapat dilaksanakan. ${ }^{17}$

\section{HAK PERBICARAAN SEGERA}

Selain terkandung dalam International Covenant on Civil and Political Rights (ICCPR) dan European Convention on Human Rights (ECHR), telah banyak keskes yang menjelaskan bahawa di dalam kes jenayah, tertuduh berhak untuk mendapatkan hak penyelesaian segera terhadap kesnya. ${ }^{18}$ Kepentingan ini adalah berdasarkan prinsip "justice delayed is justice denied". Antara kes-kes di Malaysia yang telah membincangkan prinsip ini ialah Azman bin Jamhuri $v$ Pendakwa Raya $^{19}$ dan Khairuddin bin Mohd Yusuf $v$ Pendakwa Raya. ${ }^{20}$

Persoalannya di sini ialah: Adakah hak untuk perbicaraan segera diperuntukkan di dalam undang-undang di Malaysia? Dalam hal ini, rujukan boleh dibuat kepada Perkara 5 dari Perlembagaan Persekutuan yang ada menyebut bahawa tiada seorang pun boleh diambil nyawanya atau dilucutkan kebebasan dirinya kecuali mengikut undang-undang. Selain itu, Perkara 7 Perlembagaan Persekutuan pula memberi perlindungan daripada undang-undang jenayah yang berkuatkuasa ke belakang (retrospective) dan perbicaraan berulang, manakala Perkara 8 memperuntukkan mengenai kesamarataan di sisi undangundang. Kesemua peruntukan dalam Perlembagaan Persekutuan ini memperuntukkan konsep hak dan kebebasan asasi kepada semua pihak termasuk tertuduh mahupun mangsa dalam mana-mana perbicaraan jenayah.

Perkara ini dapat dilihat di dalam kes Ong Ah Chuan $v$ Pendakwa Raya ${ }^{21}$ di mana Majlis Privy berpendapat bahawa perkataan "undang-undang" yang terkandung di dalam Perkara 5, 7 dan 8 dari Perlembagaan Persekutuan memberi jaminan akan prinsip keadilan asasi (rules of natural justice) yang sudah menjadi intipati Common Law di England. Sementara itu, berdasarkan pendapat Majlis Privy tersebut, Gopal Sri Ram FCJ di dalam kes Lee Kwan Woh v Pendakwa 
Raya $^{22}$ ada menyatakan bahawa Perkara 5(1) dari Perlembagaan Persekutuan tersebut turut merangkumi hak perbicaraan yang adil memandangkan hak tersebut adalah sebahagian penting dalam prinsip keadilan asasi. Oleh itu, sebarang perlanggaran hak-hak asasi akan menafikan hak tertuduh untuk mendapatkan satu perbicaraan yang adil dan seterusnya boleh menyebabkan berlakunya ketidakadilan.

Akan tetapi, Mahkamah Rayuan di dalam kes Pua Kiam Wee $v$ Ketua Pengarah Imigresen Malaysia \& Seorang Lagi $^{23}$ berpendapat bahawa pendekatan yang diambil di dalam kes Lee Kwan Woh di atas adalah tidak selamat kerana kes tersebut banyak dipengaruhi oleh perkembangan perundangan di India. Oleh itu, kes-kes sebelum Lee Kwan Woh adalah masih terpakai, seperti kes Kerajaan Malaysia \& Lain-lain v Loh Wai Kong $^{24}$ di mana mahkamah berpendapat bahawa frasa "kebebasan diri" yang terkandung di dalam Perkara 5(1) itu hendaklah ditafsirkan mengikut konteks penggunaannya. Begitu juga di dalam kes Pihak Berkuasa Negeri Sabah v Sugumar Balakrishnan \& Satu Rayuan Lagi ${ }^{25}$ telah dinyatakan bahawa kebebasan diri hendaklah ditafsirkan di dalam konteks Perkara 5 secara keseluruhan. Kedua-dua kes Loh Wai Kong dan Sugumar diikuti di dalam kes Majlis Agama Islam Wilayah Persekutuan v Victoria Jayaseele Martin. ${ }^{26}$ Merujuk kes-kes tersebut, mahkamah di dalam kes Pua Kim Wee di atas memutuskan bahawa Perkara 5(1) adalah berkaitan dengan isu kebebasan diri dari penahanan tidak sah sepertimana kehendak penggubalnya, dan ia tidak sepatutnya digunakan untuk mengimport hak-hak lain. ${ }^{27}$

Oleh itu, boleh dikatakan bahawa sememangnya undang-undang di Malaysia tidak memperuntukkan hak untuk dibicarakan dengan segera secara jelas. Ini adalah sejajar dengan keputusan di dalam kes Ooi Ah Phua v Pegawai Berkuasa, Penyiasatan Jenayah, Kedah/Perlis, ${ }^{28} \mathrm{di}$ mana telah disebutkan bahawa perbicaraan yang disegerakan adalah hak tidak bertulis bagi setiap orang yang dituduh melakukan sesuatu jenayah.

Namun demikian, undang-undang memberi kuasa kepada mahkamah untuk membuat penangguhan kes-kes dengan syarat ia direkodkan dan ditetapkan tarikh baru dalam jangka waktu yang munasabah. Mahkamah dikehendaki merekodkan tarikh penangguhan dibuat, tarikh baru yang dicadangkan berikutnya, dan alasan penangguhan. ${ }^{29}$ Secara tidak langsung, ini menunjukkan bahawa kesegeraan kes adalah penting di dalam undang-undang.

Dalam hal ini, kes-kes penangguhan tanpa tarikh atau sine die sangat perlu dielakkan kerana ia boleh memberi kesan kepada kualiti dan kebolehpercayaan keputusan mahkamah berhubung dengan penilaian sikap saksi yang diperiksa balas dan keterangan utama tertentu. ${ }^{30}$ Walau apapun kesudahannya terhadap tertuduh, apa yang penting ialah tertuduh mendapat penyelesaian berhubung tuduhan yang dikenakan ke atasnya dan sebarang ketidakpastian telah dihilangkan.

Dari rujukan ilmiah dan kes-kes ${ }^{31}$ boleh disimpulkan bahawa antara sebabsebab hak perbicaraan yang disegerakan perlu dititik beratkan adalah seperti berikut:

1. Ingatan saksi terhadap butiran penting kes adalah sangat diperlukan tetapi ingatan tersebut akan semakin berkurangan dengan peredaran masa, malahan dalam sesetengah kes adalah mustahil untuk menegakkan keadilan kerana kesukaran memilih versi fakta yang tepat.

2. Kebimbangan, kekecewaan, kesusahan, dan ketidakpastian yang dialami oleh tertuduh selagi mana kes belum diputuskan.

3. Kesegeraan hakim bicara menyediakan alasan penghakiman bermakna ingatan 
hakim tersebut adalah lebih jelas berkenaan semua butiran keterangan, sikap saksi-saksi, dan suasana am perbicaraan kes tersebut.

4. Dalam hal rayuan atau semakan, kesegeraan diperlukan kerana apabila sesuatu keputusan mahkamah dirayu kepada mahkamah yang lebih tinggi, ia membawa kepada penggantungan keputusan yang bermaksud bahawa kes belum selesai sepenuhnya.

\section{KUASA PENDAKWA RAYA}

Di Malaysia, kuasa pendakwaan di Malaysia terletak di bawah Pendakwaraya dan beliau mempunyai kuasa yang luas dalam menjalankan sebarang bentuk pendakwaan jenayah di mahkamah. Perkara ini telah dijelaskan di bawah Perlembagaan Persekutuan menerusi Perkara 145 Fasal (3) yang memperuntukkan bahawa:

Peguam Negara hendaklah mempunyai kuasa yang boleh dijalankan menurut budi bicaranya, untuk memulakan, menjalankan atau memberhentikan apa-apa prosiding bagi sesuatu kesalahan, selain prosiding di hadapan mahkamah Syariah, mahkamah anak negeri atau mahkamah tentera. ${ }^{32}$

Selain Perlembagaan Persekutuan, seksyen 376(1) Kanun Tatacara Jenayah (Malaysia) (Akta 593) juga memperuntukkan bahawa Peguam Negara merupakan pihak yang mempunyai kawalan dan arahan pendakwaan dalam mana-mana prosiding jenayah di bawah Kanun tersebut. Dalam membantu menjalankan tugas tersebut, seksyen 376(3) memberi kuasa kepada Pendakwa Raya untuk melantik Timbalan Pendakwa Raya yang boleh menjalankan semua kuasa Pendakwa Raya di bawah Kanun Tatacara Jenayah dan mana-mana undangundang bertulis, di bawah kawalan dan arahan am Pendakwa Raya. Selain itu, seksyen 376(3A) juga membenarkan Pendakwa Raya untuk melantik Penolong Pendakwa Raya yang mempunyai kuasa yang sama seperti Timbalan Pendakwa Raya.

Dalam kes Long bin Samat \& LainLain v Pendakwa Raya ${ }^{33}$ mahkamah telah memberikan pendapatnya mengenai betapa luasnya kuasa Peguam Negara dalam menjalankan kuasa pendakwaannya seperti yang telah diperuntukkan oleh Perkara 145 Fasal (3) Perlembagaan Persekutuan. Dalam hal ini, mahkamah ada menyatakan bahawa:

Pada pandangan mahkamah, klausa dari undang-undang agung ini jelas memberi Peguam Negara budi bicara yang sangat luas ke atas kawalan dan hala tuju semua pendakwaan jenayah. Bukan sahaja Peguam Negara boleh memulakan dan menjalankan apa-apa prosiding bagi sesuatu kesalahan, dia juga boleh memberhentikan prosidingprosiding jenayah yang telah dimulakannya, dan mahkamah tidak boleh memaksanya memulakan prosiding jenayah yang tidak kehendakinya atau meneruskan prosiding jenayah yang telah diputuskannya untuk tidak diteruskan. Lebih sedikit lagi kuasa mahkamah untuk memaksa sesuatu pertuduhan dilakukan di bawah seksyen yang memperuntukkan hukuman lebih berat seandainya Peguam Negara memilih melakukan pertuduhan yang lebih ringan. ... Sesiapa yang tidak berpuas hati dengan keputusan Peguam Negara untuk tidak mendakwa, atau tidak meneruskan pendakwaan, atau keputusannya memilih tuduhan yang lebih ringan apabila terdapat keterangan bagi kesalahan yang lebih berat yang sepatutnya didengar di hadapan mahkamah yang lebih tinggi, perlu mendapatkan penyelesaian di tempat lain, bukan di mahkamah.

Persoalan kepada kuasa budi bicara mahkamah dalam mengadili kes-kes jenayah atas kuasa pendakwaan Peguam Negara ada dibincangkan di dalam kes Karpal Singh \& Seorang Lagi v Pendakwa Raya $^{34}$ yang mana telah diputuskan bahawa kuasa budi bicara Peguam Negara di bawah Perkara 145 Fasal (3) itu adalah 
muktamad dan tidak boleh disoal atau digantikan oleh kuasa budi bicara mahkamah. Seterusnya di dalam kes Pendakwa Raya $v$ Hettiarachigae $L S$ Perera $^{35}$ di mana mahkamah telah berpendapat bahawa sehingga Peguam Negara membuat keputusannya di bawah Perkara 145, mahkamah hanya boleh menunggu dan tidak boleh merampas kuasa tersebut. Mengulas mengenai seksyen 376 Kanun Tatacara Jenayah, Mahkamah Agung di dalam kes Pendakwa Raya $v$ Zainuddin \& Seorang Lagi ${ }^{36}$ menyatakan bahawa oleh kerana kuasa mendakwa tertakluk kepada budi bicara Pendakwa Raya, mahkamah tidak boleh mengarahkan pendakwaan ditutup atau diberhentikan.

Pendirian yang disebut oleh mahkamah dalam kes-kes di atas adalah sejajar dengan yang ada di bawah Common Law di mana telah banyak keskes yang memutuskan bahawa keputusan Pendakwa Raya tidak boleh dipersoalkan. Hal ini dapat dilihat di dalam satu kes iaitu kes Director of Public Prosecutions $v$ Humphreys ${ }^{37}$ di mana telah diputuskan bahawa jika sesuatu pertuduhan telah dipilih berpandukan kuasa undang-undang, hakim tidak mempunyai kuasa untuk membatalkannya atau menolak dari mendengar kes tersebut hanya kerana tidak bersetuju dengan tindakan pendakwaaan berkenaan. Tambahan lagi, konsep kedaulatan undang-undang memberi maksud bahawa setiap sesuatu perkara itu perlu dibuat mengikut undang-undang yang dinyatakan dan pihak eksekutif tidak boleh bertindak sewenang-wenangnya kerana ia juga mesti mematuhi undangundang tersebut. ${ }^{38}$

Dalam kes yang sama juga telah diperingatkan bahawa hakim perlu berada di luar gelanggang dan tidak seharusnya, atau kelihatan seperti, bertanggungjawab memulakan pendakwaan. Jika seorang hakim berkuasa menolak dari mendengar sesuatu kes kerana berpendapat ianya tidak seharusnya dibawa ke mahkamah, maka itu seolah-olah menggambarkan bahawa pendakwaan kes-kes perlu kepada persetujuan atau kebenaran daripada seorang hakim. Keputusan ini telah diikuti di dalam kes Mohd Rafizi v Pendakwa Raya $^{39}$ Dalam erti kata lain, fungsi dan peranan hakim dan pendakwa tidak boleh bercampur-aduk dan masing-masing mempunyai kuasanya tersendiri.

Sementara itu, di dalam kes $R v$ Chairman, County of London Quarter Sessions Ex $p$ Downes ${ }^{40}$ Lord Goddard telah menjelaskan bahawa mahkamah hanya boleh menolak dari mendengar sesuatu kes dalam beberapa keadaan iaitu: (a) terdapat permohonan untuk membatalkan tuduhan lalu diputuskan bahawa ia cacat, tetapi tiada pindaan tuduhan dibuat; (b) terdapat akuan "plea in bar" dan keputusan memihak kepada tertuduh; (c) pendakwa memfailkan nolle prosequi (enggan mendakwa); atau (d) pertuduhan adalah bagi kesalahan di luar bidangkuasa mahkamah berkenaan. ${ }^{41}$

Selain kuasa prerogatif yang dimiliki, pendakwa juga dianggap mempunyai niat baik (bona fide) dalam setiap tindakannya. Sebarang dakwaan niat jahat (mala fide) di pihak pendakwa adalah fakta yang perlu dibuktikan dengan keterangan, dan fakta tersebut hanya boleh dikemukakan dan diuji ketepatannya semasa perbicaraan. ${ }^{42}$ Ini adalah mengikut keputusan dalam kes $R v$ Great Yarmouth Magistrate, Ex p Thomas, Daris \& Darlington $^{43}$ yang menyebutkan:

Dalam kes ini mahkamah majistret berhadapan dengan dakwaan niat jahat kerana pembelaan mendakwa tertuduh-tertuduh adalah mangsa penipuan yang telah menghilangkan kebebasan mereka. ... Ini adalah perkara yang hanya boleh diputuskan di dalam mahkamah majistret dengan pengemukaan bukti ... beban membuktikan ketidakjujuran diletakkan ke atas pembelaan, dan ia adalah beban yang berat. ${ }^{44}$ 


\section{KUASA KETUA PENDAKWA SYARIE}

Berbeza dari Pendakwa Raya, lantikan Ketua Pendakwa Syarie tidak dinyatakan di dalam Perlembagaan Persekutuan. Kuasa Ketua Pendakwa Syar'ie diperuntukkan di bawah Akta Pentadbiran Undang-Undang Islam (Wilayah Persekutuan) 1993 (Malaysia) (Akta 505) dan enakmen-enakmen serupa bagi negerinegeri. ${ }^{45}$ Seksyen 58(2) dan (3) dari Akta 505 memperuntukkan:

(2) Ketua Pendakwa Syarie hendaklah mempunyai kuasa yang boleh dijalankan menurut budi bicaranya bagi memulakan, menjalankan atau memberhentikan apa-apa prosiding bagi sesuatu kesalahan di hadapan Mahkamah Syariah.

(3) Ketua Pendakwa Syarie bolehlah melantik orang-orang yang layak dan sesuai daripada kalangan anggota perkhidmatan awam am Persekutuan menjadi PendakwaPendakwa Syarie yang hendaklah bertindak di bawah kawalan am dan arahan Ketua Pendakwa Syarie dan boleh menjalankan semua atau mana-mana hak dan kuasa yang terletak hak pada atau yang boleh dijalankan oleh Ketua Pendakwa Syarie sendiri. ${ }^{46}$

Bagi pelantikan dan kuasa Ketua Pendakwa Syarie di peringkat negeri pula boleh dilihat misalnya dalam seksyen 78 dari Enakmen Pentadbiran Agama Islam (Negeri Selangor) 2003 yang memperuntukkan:

(1) Duli Yang Maha Mulia Sultan, atas nasihat Majlis, boleh melantik seorang yang layak menjadi Hakim Mahkamah Tinggi Syariah untuk menjadi Ketua Pendakwa Syarie.

(2) Ketua Pendakwa Syarie hendaklah mempunyai kuasa yang boleh dijalankan menurut budi bicaranya bagi memulakan, menjalankan atau memberhentikan apa-apa prosiding bagi sesuatu kesalahan di hadapan mana-mana Mahkamah Syariah.
Perbezaan yang wujud antara Pendakwa Raya dan Pendakwa Syar'ie hanyalah dari segi bidang kuasa pendakwaan yang mana Ketua Pendakwa Syarie dan Pendakwa Syar'ie berkuasa di Mahkamah Syariah di negeri-negeri masing-masing manakala Pendakwa Raya mempunyai kuasa pendakwaan di Mahkamah Sivil dan terpakai di seluruh Malaysia kerana kuasa pendakwaan sivil merupakan bidang kuasa persekutuan. ${ }^{47}$

Akan tetapi, merujuk kesamaan frasa yang digunakan di dalam peruntukan kuasa Ketua Pendakwa Syarie di dalam Akta 505 serta enakmen negeri-negeri dengan Perkara 145 Fasal (3) Perlembagaan Persekutuan Malaysia 1957 dan seksyen 396 Kanun Tatacara Jenayah (Malaysia) (Akta 593), boleh disimpulkan bahawa Ketua Pendakwa Syarie dan Pendakwa-Pendakwa Syar'ie mempunyai kuasa dan prerogatif yang sama sepertimana diberikan kepada Pendakwa Raya. Oleh itu, perbincangan kes-kes sebelum ini adalah terpakai juga bagi Ketua Pendakwa Syarie, Pendakwa Syarie, dan Mahkamah-Mahkamah Syariah.

\section{FAKTOR-FAKTOR KELAMBATAN PERBICARAAN}

Dalam penulisan ini, "kes lambat" merujuk kepada: (a) kes-kes di mana kesalahan berlaku lama sebelum pertuduhan difailkan di mahkamah; (b) kes-kes yang telah difailkan pendakwaan tetapi perbicaraan tertangguh sebelum dimulakan; (c) kes-kes yang telah menjalani pendakwaan tetapi mengambil masa yang terlalu lama untuk diputuskan; dan (d) kes yang selesai didengar tetapi mahkamah mengambil masa yang lama untuk mengeluarkan keputusan.

dalam senario biasa perbicaraan jenayah, kelambatan kes boleh disebabkan oleh berbagai faktor, seperti contoh berikut:

1. Tempoh penyiasatan kes yang lama menyebabkan fail siasatan 
lambat diserahkan kepada pendakwa.

2. Tempoh penelitian kes yang lama di pihak pendakwa yang mungkin disebabkan oleh fakta kes yang kompleks, keterangan tidak lengkap, atau terdapat isu perundangan yang memerlukan kajian.

3. Kes telah difailkan di mahkamah tetapi perbicaraan ditangguhkan sebelum bermula disebabkan terdapat isu yang dibangkitkan secara interlokutori atau bantahan awal.

4. Kes yang telah dimulakan pendakwaan tetapi perbicaraan mengambil masa yang lama kerana wujudnya isu-isu berbangkit.

5. Mahkamah mengambil masa yang lama untuk mengeluarkan keputusan atau alasan penghakiman. ${ }^{48}$

6. Kes telah diputuskan dan sedang menjalani proses rayuan atau semakan tetapi proses tersebut mengambil masa yang lama.

\section{KESAN PROSES SIASATAN DAN PENDAKWAAN KEPADA KELEWATAN PERBICARAAN}

Sebaik sahaja kes jenayah didaftarkan di mahkamah, pertuduhan yang difailkan semestinya mengandungi tarikh atau jangka masa kesalahan dikatakan telah berlaku. Kelambatan akan dikesan jika terdapat jarak waktu yang panjang dari tarikh kejadian yang dinyatakan dan tarikh pertuduhan dibuat. Persoalan yang timbul di sini ialah: bolehkah mahkamah mempersoalkan kelambatan tersebut, dan bolehkah mahkamah menolak atau memberhentikan prosiding itu?

Dalam kes Jago v District Court of New South Wales ${ }^{49}$ yang diputuskan di Australia, mahkamah telah berdepan dengan kelambatan pendakwa mendaftarkan kes. Dalam kes itu,
Mahkamah Tinggi Australia telah memutuskan bahawa meskipun tertuduh mempunyai hak untuk mendapat perbicaraan yang adil, mahkamah tetap tidak boleh memberhentikan prosiding melainkan permohonan untuk menolak kes itu telah dibuat berasaskan prejudis atau ketidakadilan sebenar dan bukannya prejudis anggapan.

Menurut Common Law pula, mahkamah boleh memberhentikan prosiding jenayah jika terdapat penyalahgunaan proses (abuse of process) iaitu sesuatu yang sangat tidak adil dan salah di pihak pendakwa sehingga menyebabkan mahkamah tidak boleh membenarkan pendakwaan. ${ }^{50}$ Maksud "tidak adil dan salah" adalah tertakluk kepada fakta setiap kes, dengan mengambil kira keadilan terhadap pendakwa, orang awam, dan tertuduh. ${ }^{51}$ Dalam hal ini, tunjuk ajar telah diberikan di dalam kes Bennett $v$ Horseferry Road Magistrates' Court \& Seorang Lagi ${ }^{52}$ di mana mahkamah memutuskan bahawa memberhentikan prosiding berasaskan penyalahgunaan proses hanya boleh dilakukan dalam dua keadaan: (a) perbicaraan adil terhadap tertuduh adalah mustahil; dan (b) perbicaraan itu terjumlah kepada salahguna atau manipulasi proses kerana ia menyinggung keadilan mahkamah.

Persoalan seterusnya ialah sama ada kelambatan boleh menyebabkan perbicaraan adil bagi tertuduh menjadi mustahil. Soalan ini telah dijawab di dalam kes $R v$ Dunlop $^{53}$ di mana mahkamah menegaskan bahawa peredaran masa tidak menghalang keadilan dalam perbicaraan terutamanya apabila tiada bukti niat jahat atau manipulasi di pihak pendakwa, atau tertuduh sendiri yang menyumbang kepada kelambatan tersebut.

Tambahan lagi, dalam kes $R \quad v$ Gateshead Justices Ex $p$ Smith $^{54}$ telah diputuskan bahawa mahkamah perlu berhati-hati dari mencipta tempoh had masa buatan dalam keadaan ianya tidak ditetapkan di dalam undang-undang. 
Selain itu, memberhentikan prosiding juga tidak boleh dilakukan jika ia bertujuan mendisiplinkan pendakwa atau pihak yang berkuasa menyiasat. ${ }^{55}$

Perkara ini dapat dilihat dari kes $R v$ $T B F^{56}$ di mana pertuduhan telah difailkan terhadap tertuduh yang didakwa melakukan jenayah seksual sekitar 30 ke 40 tahun sebelum itu. Mahkamah mendapati bahawa Pendakwa gagal memberikan alasan yang baik di sebalik kelambatan tersebut. Lebih memburukkan keadaan apabila seorang saksi bagi tertuduh telah meninggal dunia dan kebanyakan keterangan dokumentar yang sepatutnya menjadi bukti pembelaan telah hilang. Meskipun mahkamah membatalkan sabitan bersalah terhadap tertuduh, ia tetap mengingatkan perkara-perkara berikut:

1. pemberhentian prosiding hanya boleh dilakukan setelah mahkamah berpuas hati di tahap imbangan kebarangkalian (balance of probabilities) bahawa perbicaraan adil tidak mungkin berlaku disebabkan kelambatan kes;

2. masa yang sesuai bagi tertuduh membuat permohonan pemberhentian prosiding ialah selepas semua keterangan dikemukakan;

3. dalam menilai prejudis yang dihadapi tertuduh disebabkan kelambatan kes, mahkamah perlu mempertimbangkan keterangan pembelaan yang relevan secara langsung yang telah hilang dan keterangan yang masih wujud, lalu meneliti secara kritikal akan kepentingan keterangan yang hilang itu dalam konteks keseluruhan kes;

4. setelah mengenal pasti prejudis terhadap tertuduh disebabkan kelambatan tersebut, mahkamah perlu mempertimbangkan jika ada cara untuk mengimbanginya; dan

5. mahkamah perlu mengambil kira samada kelambatan membuat aduan mengenai kesalahan tersebut adalah wajar dan samada ianya adil untuk mendakwa tertuduh setelah lama kejadian yang diadukan itu berlalu.

Kes-kes di atas jelas menunjukkan bahawa kelewatan di pihak penyiasat atau pendakwa tidak semestinya membuktikan wujudnya ketidakadilan kepada tertuduh. Berbekalkan kuasa dan anggapan baik yang diberikan kepada pihak pendakwa, tindakan pendakwaan terhadap kejadian kesalahan yang telah berlaku agak lama tidak memerlukan campur tangan mahkamah. Jika pun sekiranya tertuduh atau mahkamah sendiri berpendapat wujud prejudis atau penyalahgunaan proses dalam tindakan pendakwaan yang dibuat, mahkamah perlu membuat penelitian dengan melihat kepada keterangan yang ada. Ini bermakna mahkamah perlu terlebih dahulu memberi peluang kepada pendakwa untuk meneruskan prosiding dan mengemukakan keterangan sebelum mahkamah mempertimbangkan samada tertuduh boleh mendapat perbicaraan yang adil atau sebaliknya, sekaligus memberikan mahkamah peluang untuk menilai samada prejudis itu benar-benar wujud dan bukan anggapan semata-mata.

Merujuk kepada kedudukan perundangan di Malaysia, Kanun Tatacara Jenayah (Malaysia) (Akta 593) memperuntukkan empat keadaan di mana mahkamah boleh menggantung prosiding seperti berikut:

1. Apabila tuduhan diubah dan memerlukan sanksi terlebih dahulu di bawah seksyen 161 . Walau bagaimanapun, di dalam kes Chiew Poh Kiong $v$ Pendakwa Raya ${ }^{57}$ diputuskan bahawa walaupun tuduhan telah dipinda daripada seksyen 182 kepada seksyen 177 dari Kanun Keseksaan (Akta), oleh kerana kedua-dua tuduhan berkaitan dengan fakta yang sama, maka sanksi yang telah diberikan 
sebelum pindaan tersebut dibuat tidak perlu diperbaharui.

2. Dalam keadaan tertuduh dipertuduhkan dengan lebih dari satu tuduhan lalu disabitkan bersalah di bawah salah satu atau lebih dari tuduhan-tuduhan tersebut, dan mahkamah menggantung prosiding bagi baki pertuduhan, samada atas permohonan pendakwa atau atas persetujuan mahkamah itu sendiri bawah seksyen 171(1). Penggantungan prosiding atas permohonan pendakwa boleh dilihat di dalam kes Pendakwa Raya v Ignatius Anak James. ${ }^{58}$

3. Jika mahkamah berpendapat kesalahan yang dipertuduhkan patut dibicarakan oleh mahkamah yang lebih tinggi di bawah seksyen 177. Di dalam kes Raja Petra bin Raja Kamaruddin $v$ Pendakwa Raya ${ }^{59}$ pendakwa telah memohon supaya kes dipindahkan ke mahkamah yang lebih tinggi kerana kes tersebut "melibatkan kepentingan awam". Mahkamah Tinggi Kuala Lumpur memutuskan bahawa perintah pindahan yang dibuat oleh pihak pendakwaan mengikut seksyen 177 Kanun Tatacara Jenayah adalah sah dan teratur dan tidak bercanggah dengan peruntukan Perkara 8(1) Perlembagaan Persekutuan.

4. Apabila pendakwa memberitahu mahkamah dia tidak akan mendakwa tertuduh selanjutnya (nolle prosequi) di bawah seksyen 254. Peruntukan ini boleh dilihat contohnya di dalam kes Tan Chow Cheang $v$ Pendakwa Raya $^{60}$ di mana pendakwa telah dikejutkan dengan tindakan tertuduh mengeluarkan rakaman CCTV sewaktu pemeriksaan balas salah seorang saksi pendakwaan. Selepas selesai pemeriksaan saksi tersebut, pendakwa telah memohon untuk melepaskan tertuduh tanpa pembebasan sementara menunggu rakaman tersebut diperiksa dari segi forensik. Mahkamah Rayuan memutuskan bahawa mahkamah bicara adalah betul dalam membenarkan permohonan tersebut.

Selain empat keadaan di atas, tiada peruntukan yang membolehkan perbicaraan diberhentikan atas sebab kelambatan mengemukakan pendakwaan. Oleh itu, melainkan dalam kesalahankesalahan yang ditetapkan tempoh had masa, tidak wujud halangan bagi pihak pendakwa untuk mempergunakan kuasanya secara sah menurut undangundang, dan tiada keperluan baginya untuk memberikan penjelasan di sebalik keputusannya untuk mendakwa.

\section{KELAMBATAN DI PIHAK MAHKAMAH}

Dalam kes Azman bin Jamhuri $v$ Pendakwa Raya, ${ }^{61}$ mahkamah merujuk kejadian yang berlaku di England dalam tahun 1998 ketika mana seorang hakim telah diambil tindakan kerana mengambil masa yang terlalu lama untuk memberikan alasan penghakiman, seperti juga dalam beberapa kes lain. Berikutan itu, mahkamah dalam kes Azman berpendapat bahawa mahkamah-mahkamah di Malaysia perlu menggunakan piawaian yang sama, terutama sekali dalam kes-kes jenayah yang sepatutnya mengambil masa yang lebih singkat berbanding kes-kes sivil. $^{62}$

Kelambatan di pihak mahkamah boleh berlaku dalam dua cara: kelambatan dalam membuat keputusan; dan kelambatan dalam mengeluarkan alasan penghakiman bertulis. Dalam kes Amathevelli $P$ Ramasamy v Pendakwa Raya, ${ }^{63}$ mahkamah menerangkan bahawa dalam sesetengah kes, keputusan dibuat terlebih dahulu dan alasan bertulis akan 
diberikan kemudian, manakala dalam sesetengah kes yang lain pula, mahkamah menangguhkan perbicaraan dan membuat keputusan berserta alasan bertulis pada suatu tarikh yang ditetapkan kemudian. Dalam hal ini, mahkamah di dalam kes Amathavelli berpendapat bahawa untuk menyegerakan perbicaraan, kaedah kedua adalah lebih baik kerana pada tarikh tersebut, mahkamah akan dapat memberikan keputusan serta alasan penghakiman pada waktu yang sama. Ini juga akan dapat mempercepatkan proses rayuan berikutnya jika ada, di mana pihak pengurusan mahkamah tidak akan mengambil masa yang lama dalam menyediakan rekod rayuan memandangkan alasan penghakiman bertulis sudah tersedia.

Mahkamah dalam kes Balasingham $v$ Pendakwa Raya ${ }^{64}$ telah memutuskan bahawa mahkamah bicara terikat dengan kehendak undang-undang di bawah seksyen 308 Kanun Tatacara Jenayah untuk menyerahkan alasan penghakiman kepada mahkamah yang akan mendengar rayuan, iaitu dalam bentuk keputusan beralasan mengenai fakta dan perundangan dan bukan sekadar kesimpulan yang dicapai.

Kelewatan mahkamah dalam menyediakan alasan penghakiman boleh menyebabkan prejudis terhadap tertuduh yang membuat rayuan. Ini kerana hakim bicara mungkin tertinggal untuk menyatakan sesuatu yang mungkin menguntungkan tertuduh dalam alasan penghakimannya. Ini telah diputuskan di dalam kes TN Nathan $v$ Pendakwa Raya ${ }^{65}$ di mana hakim bicara telah menyiapkan alasan penghakiman 11 bulan selepas perbicaraan selesai.

Persoalan-persoalan yang timbul di sini ialah: bolehkah kelambatan perbicaraan yang disebabkan oleh mahkamah mewajarkan pembuangan kes? Adakah kelambatan itu dengan sendirinya menyebabkan prejudis terhadap tertuduh lalu menjadikan pensabitan kesalahannya tidak selamat?
Dalam kes Barton $v R^{66}{ }^{66}$ mahkamah memutuskan bahawa ukuran keadilan yang perlu diguna pakai hendaklah seimbang kerana kepentingan tertuduh tidak boleh dipertimbangkan tanpa mengambil kira hak masyarakat yang mengharapkan orang-orang yang dituduh melakukan kesalahan jenayah dibawa ke muka pengadilan. ${ }^{67}$ Dalam masa yang sama, masyarakat juga menghendaki perbicaraan yang adil dan didengarkan dalam tempoh masa yang munasabah.

Dalam kes Tan Hun Wah $v$ Pendakwa Raya \& Rayuan Satu Lagi ${ }^{68}$ mahkamah telah memutuskan:

Dalam kes ini, hakim bicara mengambil kirakira lima tahun untuk mengeluarkan alasan penghakiman kepada tertuduh. Ianya dikesali, tetapi mahkamah sependapat dengan Mahkamah Agung bahawa ia tidak semestinya membatalkan keseluruhan prosiding. Apatah lagi apabila tidak ditunjukkan dalam nota keterangan bahawa perayu telah mengalami prejudis kesan dari penangguhan tersebut. Tambahan pula, mahkamah berpendapat bahawa dalam pentadbiran keadilan, mahkamah-mahkamah mesti bersikap adil bukan sahaja kepada tertuduh, bahkan kepada Kerajaan dan masyarakat. Adalah tidak adil kepada Kerajaan dan masyarakat yang membuat dan mentadbir undang-undang jenayah, jika tertuduh diberikan kebebasan secara langsung hanya disebabkan kelambatan dalam pengeluaran alasan penghakiman. ${ }^{69}$

Dalam kes yang sama turut
diputuskan:

Prinsip "justice delayed is justice denied" adalah bersifat umum, dan ia tidak bermakna bahawa setiap bentuk kelambatan, walaupun mahkamah tidak mempersetujuinya, sepatutnya membatalkan keseluruhan prosiding. Walau bagaimanapun, prinsip perbicaraan adil perlu lebih ditekankan jika kelambatan yang berlebihan itu bukan disebabkan oleh pendakwa tetapi mahkamah bicara itu sendiri.

Begitu juga di dalam kes Amathevelli yang disebutkan sebelum ini yang mana 
Mahkamah Rayuan telah berpendapat bahawa kelambatan hakim bicara mengeluarkan penghakiman bertulis tidak secara automatik akan membatalkan atau mengenepikan keputusan hakim tersebut. ${ }^{70}$

Berdasarkan rujukan kes-kes di atas, kes-kes tertangguh tidak boleh dibatalkan atau diketepikan semata-mata kerana kelambatan dalam menyelesaikannya. Apabila berhadapan dengan persoalan sama ada untuk meneruskan pendengaran kes yang tertangguh, mahkamah perlu melihat beberapa faktor seperti tempoh penangguhan, tanggungjawab tertuduh mengemukakan hak-haknya, dan paling penting prejudis yang dialami oleh tertuduh disebabkan penangguhan tersebut. $^{71}$ Dalam apa keadaan sekalipun, pembuangan kes hanya boleh dilakukan dalam keadaan yang ekstrim, dan membuat perintah tersebut semata-mata disebabkan kelambatan kes seharusnya sangat jarang berlaku. ${ }^{72}$

Pengecualian dari peraturan ini hanya boleh diberikan jika terdapat alasan lain yang memberatkan keperluan mengenepikan kes tersebut. Sebagai contoh, di dalam kes Voon Chin Fatt $v$ Pendakwa Raya ${ }^{73}$ di samping kelambatan hakim bicara selama dua tahun dalam memberikan alasan penghakiman, mahkamah rayuan juga mengambil kira kekeliruan dalam penerimaan keterangan yang tidak dapat mempertahankan sabitan bersalah tertuduh. ${ }^{74}$ Dalam erti kata lain, tertuduh perlu melangkah setapak lagi dengan membuktikan prejudis terhadap dirinya disebabkan penangguhan itu sebelum keputusan membatalkan prosiding dibuat.

\section{KESIMPULAN}

Daripada perbincangan dalam kajian ini, terdapat dua dapatan penting yang boleh diambil perhatian. Pertama, kuasa campur tangan mahkamah adalah terhad disebabkan kuasa prerogatif yang diberikan kepada pendakwa menurut undang-undang. Kedua, adalah suatu kepentingan untuk menyeimbangkan di antara hak tertuduh dengan hak kerajaan dan hak masyarakat. Justeru itu, adalah dicadangkan agar semua pihak yang terlibat dalam setiap proses perbicaraan jenayah, iaitu penyiasat, mahkamah, pendakwa, peguam bela, dan tertuduh memastikan tugas masing-masing berjalan dengan cepat, lancar, dan sempurna demi kepentingan semua pihak. Dalam hal ini, hak tertuduh untuk mendapat perbicaraan yang segera perlu dijaga menurut prinsipprinsip undang-undang yang telah ditetapkan. Adalah diakui bahawa kelambatan kes akan menyebabkan kesukaran di pihak tertuduh untuk membuat pembelaan yang baik. Akan tetapi, tidak boleh dinafikan bahawa kesukaran yang sama juga turut dihadapi oleh pihak pendakwaan yang memikul beban membuktikan kesalahan tertuduh melampaui keraguan munasabah. ${ }^{75}$ Seperti keputusan mahkamah dalam kes Yunani bin Abdul Hamid $v$ Pendakwa Raya ${ }^{76}$ prejudis yang dialami oleh tertuduh berikutan kelambatan perbicaraan bukanlah prejudis yang tidak boleh diperbaiki atau diundur semula. Apa yang lebih diutamakan ialah kepentingan tertuduh sendiri yang mana tuduhan yang dikenakan ke atasnya berkesudahan, di mana 'pedang' yang selama ini tergantung di atas dirinya akan akhirnya tersarung juga. 


\section{NOTA}

2 Kenneth Bresler. Constitutional Law for Criminal Justice Professional and Students. Amerika Syarikat: Springfield, 2014. P. 142.

3 Lee, Chong Fook, Habibah Kiprawi dan Che Audah Hassan. The Process of Criminal Justice: Part II -Trial Proceedings, Sentencing and Appeals. Malaysia: Lexis Nexis, 2010. P.342.

4 Di Malaysia, plea bargaining telah diperkenalkan dalam seksyen $172 \mathrm{C}$ Kanun Tatacara Jenayah (Akta 593) pada tahun 2010.

5 Angela J. Davis. Prosecution and Race: The Power and Privilege of Discretion. Dalam. Susan D. Carle (pnyt.). Lawyer's Ethics and the Pursuit of Social Ethics: A Critical Reader, New York: New York University Press, 2005, p. 249.

6 Jefferson L. Ingram. Criminal Evidence, Ed. 12. Amerika Syarikat: Elsevier, 2005, p. 154. Sebagai contoh, di Malaysia, wujud anggapananggapan tertentu di dalam Akta Keterangan (Akta 56) seperti anggapan tentang ketulenan salinan diperakui di bawah seksyen 79 . Berdasarkan anggapan tersebut, pihak yang mengemukakan dokumen tersebut tidak perlu membuktikan ketulenannya di mahkamah.

7 Muhammad Salam Madkur, Al-Qada fi alIslam. Kaherah: Matbaah al-Nahdah, 1964, p. 46.

8 Abu al-'Abbas Shababuddin Ahmad bin Idris bin Abd al-Rahman Al-Qarafi. Al-Ihkam fi Tamyiz al-Fatawa 'an al-Ahkam wa Tasarrufat al-Qadi wa al-Imam. Lubnan: Dar al-Bashair al-Islamiyyah, 1995, p. 143. Contoh syaratsyarat tersebut ialah syarat-syarat kesaksian dan pembuktian dakwaan oleh pihak yang mendakwa.

9 Ibid.

10 Muhammad Salam Madkur (n7), 51

11 Mahmud Zaki Fuad, Pembaharuan Dalam Undang-Undang Islam: Kajian Terhadap Status Hakim Wanita di Indonesia. Tesis Sarjana Syariah, Universiti Malaya, 2002, p. 104.

12 Yusuf al-Qaradhawi. Fatwa Kontemporari Jilid 1, Siri 4 (Hubungan Kemasyarakatan), Terj. Shafiyah Abdul Khodir. Selangor: PTS Islamika, 2015, 21.

13 Wahbah al-Zuhaili,. Al-Fiqh Al-Islami Wa Adillatuhu. Terj. Abdul Hayyie al-Kattani. Jil. 5. Indonesia: Gema Insani, 2007, 99.

14 Mahir Abdul Majid Abbood. Some Guarantees of Justice in the Islamic Judiciary, (2007) 35:. Al-Adl, 106-160, p.138.

15 Abdul Karim Zaidan.. Nizam Al-Qada fi AlShariah Al-Islamiah. Beirut: Muassasah AlRisalah, 1989, p.258. Dr. Abdul Karim Zaidan (1917-2014) terkenal sebagai tokoh dakwah dan pemikir Islam, menjadi pakar rujuk, dan telah menulis lebih daripada 10 buah buku dalam bidang Syariah, perundangan, dan pendidikan Islam. Semasa hayatnya, beliau telah menyandang jawatan-jawatan akademik sebagai pensyarah dan Ketua Jabatan Syariah Islamiah di Universiti Baghdad, pensyarah Syariah Islamiah di Universiti San'aa, dan pensyarah di Jabatan Fiqh dan Usul Fiqh di Universiti Iman di San'aa. Antara pencapaian tertinggi beliau ialah anugerah khas Diraja dari Raja Arab Saudi dalam pengajian Islam pada tahun 1997.

16 YAA Haji Othman bin Ibrahim. Perutusan Ketua Hakim Syar'ie, Jabatan Kehakiman Syariah Negeri Perlis. http://perlis.jksm.gov.my/jk snperlis/index.php/en/profil-jabatan/perutusanketua-hakim-syarie/perutusan-ketua-hakimsyarie [25 Januari 2018].

17 Ragunath Kesavan. Speech by Chairman of the Bar Council at the Opening of the Legal Year 2011. (2011) 4 Malayan Law Journal, c-cvi,p. ci.

18 Hak untuk dibicarakan tanpa kelewatan tidak wajar di bawah Perkara 14(3)(c) ICCPR dan Perkara 5(3) ECHR, serta hak kepada perbicaraan adil dan cepat di bawah Perkara 9(3) ICCPR dan Perkara 6(1) ECHR.

19 [2000] MLJU 702.

20 [2005] MLJU 662.

21 [1981] 1 MLJ 64.

22 [2009] 5 CLJ 631.

23 [2017] MLJU 902.

24 [1979] 2 MLJ 33.

25 [2002] 4 CLJ 105.

26 [2016] 2 MLJ 309.

27 Laporan Suruhanjaya Reid (Report of the Federation of Malaya Constitutional Commission) 1957. Bab IX, perenggan 162.

28 [1975] 1 MLJ 93

29 Seksyen 176(2)(o) Kanun Prosedur Jenayah (Malaysia) (Akta 593).

30 Tan Hun Wah v Pendakwa Raya [1994] 1 AMR 113; [1994] 1 MLJ 382.

31 Sebagai contoh, lihat: kes-kes Birkett v James [1978] AC 297, 327; Regina v Lawrence [1982] AC 510, 517; Voon Chin Fatt $v$ Public Prosecutor [1948-49] MLJ Supp 133; dan kertas kerja Azahar bin Mohamed. 2015. Courts Reform Programmes: The Malaysian Experience. Kertas kerja Seminar Fello Inns of Court. Anjuran Institute of Advanced Legal Studies, University of London. London, 1 Disember.

32 Kedudukan ini berbeza dari India dan United Kingdom di mana jawatan-jawatan Peguam Negara dan Pendakwa Raya dijawat oleh dua individu berlainan.

33 [1974] 2 MLJ 152. 
34 [1991] 2 MLJ 544.

[1997] 1 MLJ 12.

[1986] 2 MLJ 100.

[1976] 2 All ER 497.

38 Ahmad Zaharuddin Sani Ahmad Sabri. 2014. Raksa Raya Malaysia. Kuala Lumpur: Institut Terjemahan \& Buku Malaysia Berhad, 146.

39 [2014] 3 MLJ 114.

40 [1954] 1 QB 1.

41 "Plea in bar" merujuk kepada akuan yang boleh membatalkan prosiding, contohnya akuan autrefois acquit dan autrefois convict.

42 Long bin Samat [1974] 2 MLJ 152.

43 [1992] Crim LR 116.

44 Kes ini diikuti di dalam kes $R v$ Stubley, $R v$ Wardle [1999] QB 822.

45 Pelantikan Ketua Pendakwa Syarie bagi negerinegeri diperuntukkan di bawah enakmen negeri kerana Agama Islam terletak di bawah Bidang Kuasa Negeri merujuk Jadual 9 Senarai 2 Perlembagaan Persekutuan. Terdapat tiga senarai di dalam Perlembagaan Persekutuan iaitu: (a) Senarai Persekutuan yang menyenaraikan perkara-perkara yang terletak di bawah kuasa Parlimen; (b) Senarai Negeri yang menyenaraikan perkara-perkara yang terletak di bawah kuasa Dewan Undangan Negeri; dan (c) Senarai Bersama yang menyenaraikan perkaraperkara yang mana Parlimen dan Dewan Undangan Negeri boleh menggubal undangundang.

46 Sebagai perbandingan, di Negara Brunei Darussalam, terdapat satu klausa tambahan yang menekankan kebebasan Ketua Pendakwa Syarie dalam menjalankan kuasa tersebut. Seksyen 25(3) dari Akta Mahkamah-Mahkamah Syariah 1998 (Brunei) (Penggal 184) berbunyi: "Pada menjalankan kuasa ini Ketua Pendakwa Syarie tidak tertakluk kepada arahan atau kawalan mana-mana orang lain atau pihak berkuasa".

47 Jadual 9 Perlembagaan Persekutuan.

48 Seperti yang berlaku di dalam kes Tan Hun Wah $v$ Pendakwa Raya \& Rayuan Satu Lagi (n28).

49 [1989] HCA 46.

50 Hui Chi Ming v R [1992] 1 AC 34.

51 DPP v Meakin [2006] EWHC 1067.

52 [1993] 3 All ER 138.

53 [2006] EWCA Crim 1354; [2007] 1 Cr App R 8.

54 (1985) 149 JP 681.

$55 \quad R v$ Crown Court Ex p Belsham (1992) $94 \mathrm{Cr}$ App $\quad$ R 382 QBD; $R \quad v$ Methyr Tydfil Magistrates' Court Ex p DPP [1989] Crim L R 148.

56 [2011] EWCA Crim 726.

57 [2001] 4 MLJ 280.

58 [2011] MLJU 1515.
59 [2009] MLJU 194.

60 [2017] MLJU 1642.

61 [2000] MLJU 702.

62 Di Mahkamah-Mahkamah Syariah, kes-kes sivil disebut sebagai kes-kes mal iaitu kes-kes bukan jenayah seperti kes perceraian dan perwarisan harta.

63 [2009] 3 CLJ 109; [2009] 2 AMR 281.

64 [1959] MLJ 193.

65 [1978] 1 MLJ 134.

66 (1980) 147 CLR 75.

67 (1980) 147 CLR 75, 102, 106.

68 [1994] 1 AMR 113.

69 Tan Hun Wah (n28).

70 [2009] MLJU 6.

71 Barker $v$ Wingo (1972) 407 US 514; Bell v DPP [1985] AC 937, seperti diterangkan di dalam Watson \& Gorman v Fitzpatrick (1987) 32 A Crim R 330.

72 Re Cooney (1987) 31 A Crim R 256, 263-264.

73 [1948-1949] MLJ Supp 131.

[1948-1949] MLJ Supp 131.

Seksyen 180 Kanun Prosedur Jenayah. [2008] 3 SLR 383.

\section{RUJUKAN}

Abdul Karim Zaidan. 1989. Nizam AlQada fi Al-Shariah Al-Islamiah. Beirut: Muassasah Al-Risalah.

Abu al-'Abbas Shababuddin Ahmad bin Idris bin Abd al-Rahman Al-Qarafi. 1995. Al-Ihkam fi Tamyiz al-Fatawa 'an al-Ahkam wa Tasarrufat al-Qadi wa al-Imam. Lubnan: Dar al-Bashair al-Islamiyyah.

Ahmad Zaharuddin Sani Ahmad Sabri. 2014. Raksa Raya Malaysia. Kuala Lumpur: Institut Terjemahan \& Buku Malaysia Berhad.

Azahar Mohamed. 2015. Courts Reform Programmes: The Malaysian Experience. Kertas kerja Seminar Fello Inns of Court. Anjuran Institute of Advanced Legal Studies, University of London. London, 1 Disember.

Bresler, K. 2014. Constitutional Law for Criminal Justice Professional and Students. Amerika Syarikat: Springfield.

Davis, A. J. 2005. Prosecution and Race: The Power and Privilege of 
Discretion. Dlm. Lawyer's Ethics and the Pursuit of Social Ethics: A Critical Reader, disunting oleh Susan D. Carle, 245-257. New York: New York University Press.

Ingram, J. L. 2005. Criminal Evidence. $12^{\text {th }}$ edition. Amerika Syarikat: Elsevier.

Laporan Suruhanjaya Reid (Report of the Federation of Malaya Constitutional Commission) 1957. Bab IX, perenggan 162.

Lee, Chong Fook, Habibah Kiprawi dan Che Audah Hassan. 2010. The Process of Criminal Justice: Part II -Trial Proceedings, Sentencing and Appeals. Malaysia: Lexis Nexis, 342.

Mahir Abdul Majid Abbood. 2007. Some Guarantees of Justice in the Islamic Judiciary. Al-Adl 35: 106-160, 138.

Mahmud Zaki Fuad. 2002. Pembaharuan Dalam Undang-Undang Islam: Kajian Terhadap Status Hakim Wanita di Indonesia. Tesis Sarjana Syariah, Universiti Malaya, 104.

Muhammad Salam Madkur. 1964. AlQada fi al-Islam. Kaherah: Matbaah al-Nahdah, 46.

Ragunath Kesavan. 2011. Speech by Chairman of the Bar Council at the Opening of the Legal Year 2011. Malayan Law Journal 4:c-cvi, ci.

Wahbah al-Zuhaili, 2007. Al-Fiqh AlIslami Wa Adillatuhu. Terj. Abdul Hayyie al-Kattani. Jil. 5. Indonesia: Gema Insani, 99.

YAA Haji Othman bin Ibrahim. Perutusan Ketua Hakim Syar'ie, Jabatan Kehakiman Syariah Negeri Perlis.http://perlis.jksm.gov.my/jksn perlis/index.php/en/profiljabatan/perutusan-ketua-hakimsyarie/perutusan-ketua-hakim-syarie [25 Januari 2018].

Yusuf al-Qaradhawi. 2015. Fatwa Kontemporari Jilid 1, Siri 4 (Hubungan Kemasyarakatan), Terj.
Shafiyah Abdul Khodir. Selangor: PTS Islamika, 21.

Muhammad Salam Madkur. 1964. AlQada fi al-Islam. Kaherah: Matbaah al-Nahdah, 46.

Fatimah Haji Ahmad

Pelajar Fakulti Undang-Undang,

Universiti Malaya.

E-mel: fatimah129@hotmail.com

Zulazhar Tahir

Pensyarah Fakulti Undang-Undang,

Universiti Malaya.

E-mel: zulazhar@um.edu.my.

Md Khalil Ruslan

Pensyarah Fakulti Undang-Undang,

Universiti Malaya.

E-mel: mkruslan@um.edu.my 